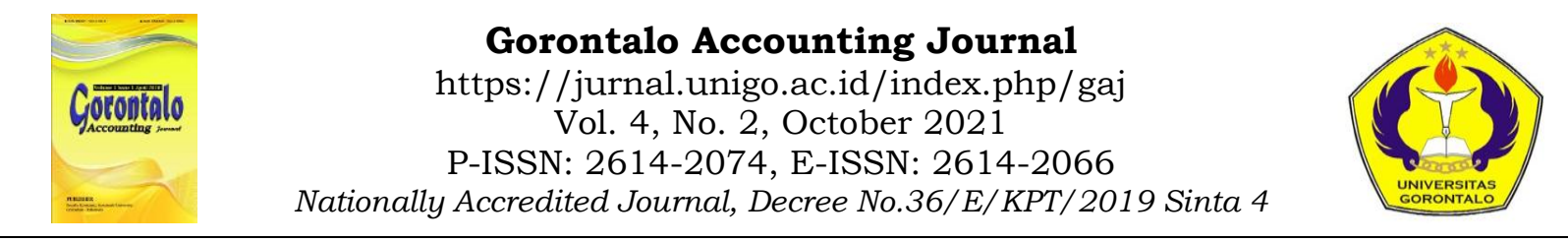

\title{
Gejala Patologi Birokrasi Pemerintah Desa Dan Pengaruhnya Terhadap Keberhasilan Pengelolaan Dana Desa
}

\author{
Nur Lazimatul Hilma Sholehah', Parmin Ishak ${ }^{2}$ \\ 1,2 Universitas Ichsan Gorontalo/J1. Drs. Achmad Nadjamuddin No.10, Dulalowo Timur, \\ Kota Tengah, Kabupaten Gorontalo, Gorontalo 96115/Indonesia \\ 1nurlazimatul72@gmail.com, 2parminishak72@gmail.com
}

Citation: Sholehah, N. L. H. \& P. I. (2021). Gejala Patologi Birokrasi Pemerintah Desa Dan Pengaruhnya Terhadap Keberhasilan Pengelolaan Dana Desa. Gorontalo Accounting Journal 4(2), 133-145. DOI: $10.32662 /$ gaj.v4i2.1593

\section{Artikel info}

\section{Artikel history:}

Received: 13-06-2021

Revised:13-08-2021

Accepted: 15-08-2021

\section{Keywords:}

Bureaucratic;

Pathology;
Abstract. This study purposed to analyze the indication of birtocratic pathology of the village government and its effect on the success of village fund budgeting management by applying the variable dysfunction of bureaucracy and administrative mall as independent variables and accountability as the dependent variable. This research is applying descriptive analysis research methods and multiple regression with 98 participants from the staff of the village offices in Wonosari sub district. As the results, this study shows that simultaneously dysfunction of bureaucracy and mall administration have a significant effect on accountability, while partially the variable Disfunction of bureaucracy does not have a significant effect. On the other hand, mall administration has a significant effect on the accountability of the village government.

Abstrak. Penelitian ini bertujuan untuk melihat seberapa besar gejala patologi birokrasi pemerintah desa dan pengaruhnya terhadap keberhasilan pengelolaan anggaran dana desa dengan menggunakan variabel Disfunction of bureaucracy dan mall administrasi sebgai variabel independen dan akuntabilitas sebagai variabel dependen dan menggunakan metode penelitian analisis deskriptif dan analisis regresi berganda dengan sampel aparat desa seKecamatan Wonosari yang berjumlah 98 orang. Berdasarkan hasil penelitian menunjukan bahwa secara simultan Disfunction of bureaucracy dan mall administrasi berpengaruh signifikan terhadap akuntabilitas, sementara secara parsial variabel Disfunction of bureaucracy tidak memberikan pengaruh yang signifikan namun mall adminitrasi memberikan pengaruh yang signifikan terhadap akuntabilitas pemerintah desa.

Coresponden author: parminishak72@gmail.com 


\section{Pendahuluan}

Penelitian ini bertujuan untuk melihat gejala patologis yang terjadi pada birokrasi pemerintah desa yang akan berpengaruh terhadap keberhasilan pengelolaan dana desa. Banyak penelitian-penelitian yang membahas tentang patologi birokrasi, namun patologi birokrasi pada riset ini lebih rinci membahas tentang gejala-gejala patologi yang ada pada birokrasi pemerintahan desa yang tentunya akan memberikan dampak terhadap keberhasilan pengelolaan alokasi dana desa. Pemerintah desa merupakan top manajemen pada tingkat desa, atau merupakan unsur pemerintahan yang ada pada tingkat desa. Pemerintah desa mengelola pemerintahannya dengan menggunakan dana desa yang bersumber dari APBN dan alokasi dana desa dari APBD, sehingga dalam menjalankan roda pemerintahannya harus benar-benar bersih, dan terhindar dari penyakit (patologi) birokrasi pemerintah dengan tujuan meningkatkan keberhasilan pengelolaan dana desa, karena indikator utama keberhasilan pengelolaan dana desa adalah transparansi dan akuntabilitas.

Perilaku birokrasi saat ini cenderung resisten terhadap pembaharuan yang dapat berpotensi terhadap tindakan kecurangan yang dapat menimbulkan penyakit pada tubuh birokrasi (Wakhid, 2011). Birokrasi akan baik perilakunya jika karakter individu dan birokrasi harus berinteraksi dengan baik pula, begitu pula sebaliknya, jika tidak terpenuhi interaksi tersebut maka akan terjadi perilaku birokrasi yang tidak baik yang akan menimbulkan penyakit birokrasi (Wakhid, 2011). Saat ini penyakit birokrasi tidak hanya bisa terjadi pada pemerintah pusat, tetapi justru semakin berkembang sangat luas di tataran pemerintah desa/kelurahan sebagai struktur paling bawah dalam sistem penyelenggaraan Negara (Khoiron, 2019). Besarnya dana yang harus dikelola oleh pemerintah desa semakin membuka peluang timbulnya penyakit birokrasi di tataran desa. Penggunaan dana desa yang tidak sesuai dengan peruntukkannya sering kali menimbulkan permasalahan klasik dalam sistem pembangunan desa (Muliadi, 2019).

Secara umum setidaknya ada beberapa model tindakan korupsi yang sering dilakukan oleh pemerintah desa melalui pernyataan ICW dalam laporannya di tahun 2019, di antaranya adalah, kegiatan markup, pungutan liar, penyalahgunaan wewenang, laporan fiktif, pemotongan anggaran, penggelapan hingga kasus suap. setidaknya ada 14 potensi masalah yang mencakup regulasi dan kelembagaan, tata laksana, hingga pengawasan dan aspek SDM, hal tersebut dijelaskan oleh KPK berdasarkan hasil inventarisir komisi pemberantasan korupsi (Khoiron, 2019). Berdasarkan data ICW menunjukkan bahwa ada sebanyak 46 kasus korupsi anggaran dana desa yang terjadi selama tahun 2019 yang menyebabkan kerugian Negara hingga 32,3 miliar rupiah. Permasalahan yang demikian ini menjadi akibat dari belum diterapkannya akuntabilitas secara menyeluruh sehingga praktik-praktik patologi birokrasi seperti KKN menjadi karakter tipikal yang cenderung melekat (Trihastuti, 2014).

Melihat begitu maraknya patologi yang melekat pada birokrasi, maka perlu ada tindakan pencegahan dini untuk memperbaiki birokrasi ke arah yang lebih baik serta menjawab segala kepentingan yang menjadi harapan rakyat dengan memperbaiki aspek pertanggungjawaban dengan menerapkan akuntabilitas yang mempu memenuhi kriteria birokrasi. Penyakit birokrasi sudah menjamur hingga ke daerah-daerah termasuk di Provinsi Gorontalo yang menambah daftar panjang penyelewengan anggaran yang seharusnya diperuntukkan untuk kesejahteraan masyarakat. Di Kabupaten Boalemo sendiri kasus dugaan tindak pidana korupsi terkuak di awal tahun 2020 dengan dikeluarkannya berita pemberhentian salah satu kepala desa yang saat ini kasusnya sementara ditangani oleh Kejaksaan 
(faktanews.com). Berdasarkan fenomena yang telah diuraikan maka tujuan utama penelitian ini untuk mengetahui gejala patologi birokrasi pemerintah desa dan pengaruhnya terhadap keberhasilan pengelolaan dana desa.

\section{Tinjauan Teoritis}

\section{Theory of Reasoned Actio (TRA)}

Pertama kali teori ini diperkenalkan dan dikembangkan oleh Ajzen di tahun 1980 (Ishak, 2018). Ajzen mengembangkan teori ini berdasarkan perilaku manusia yang secara sadar dalam melakukan tindakan serta melakukan pertimbangan atas informasi yang ada. Ajzen (1980) dalam Theory of Reasoned Action (TRA) menjelaskan bahwa perilaku yang dilakukan seseorang berawal dari niatan dan hal tersebut akan mempengaruhi tindakan perilakunya. Selanjutnya Ajzen menjelaskan bahwa ada beberapa faktor yang mendasari manusia dalam melakukan tindakan perilakunya, diantaranya yang pertama adalah yang berkaitan dengan perilaku dan sikap (behavior an attitude) dan yang kedua adalah yang berkaitan dengan pengaruh sosial yakni norma subjektif.

\section{Patologi Birokrasi}

Secara etimologi patologi memiliki makna sebagai ilmu yang berhubungan dengan penyakit yang di adopsi dari istilah kedokteran. Jika diartikan dalam ilmu sosial patologi birokrasi adalah penyakit yang oleh manusia dalam bentuk perilaku yang bertentangan norma yang berlaku, bertentangan dengan perilaku etis, menentang ketentuan perundang undangan hingga perilaku yang menyimpang dari berbagai aspek yang berlaku pada birokrasi (Mantiri, 2017). Sedangkan Smith (1998) dalam (H. M. Ma'ruf, 2010) menjelaskan ada 2 konsep yang terjadi pada ruang lingkup patologi birokrasi, diantaranya adalah Disfunction of bureaucracy dan Mal-administration. Selanjutnya dijelaskan bahwa Disfunction of bureaucracy perilaku yang berkaitan erat dengan karakter birokrasi, pada dasarnya perilaku ini berkaitan dengan kelembagaan, prosedur dan mekanisme, aturan hingga struktur, sehingga mewujudkan kinerja yang buruk atau tidak maksimal. Disisi lain Maladministration, berkaitan erat dengan kualitas sumber daya manusia yang ada dalam birokrasi yang sangat berkaitan erat dengan perilaku penyogokan yang meliputi, perilaku arogan, senstif, perilaku korup, tidak peduli dan lain sebagainya.

\section{Akuntabilitas}

(Diarespati, 2017) menjelaskan bahwa akuntabilitas merupakan alat pengendali yang dilakukan dalam pemerintahan terhadap aparatur atas apa yang dilakukan, hingga pemerintah memiliki peran yang penting dalam mempertanggungjawabkan kinerja pemerintahan kepada khalayak umum dalam hal ini adalah rakyat atau prinsipal. Salah satu penyebabnya maraknya Fraud di indonesia diakibatkan oleh rendahnya akuntabilitas kinerja anggaran pada sektor pemerintah yang ada di Indonesia (Sholehah, 2019). Pada dasarnya akuntabilitas merupakan hubungan antara agen dalam menggambarkan kinerjanya kepadapihak yang memberikan tanggungjawabnya (Meutia, 2020). dari uraian sebelumnya maka dapat digambarkan bahwa akuntabilitas adalah sebuah prinsip yang tertanam dalam diri aparatur negara untuk mempertanggungjawabkan kinerja yang telah dilaksanakan kepada khalayak umum

\section{Pengelolaan Keuangan Desa}

Peraturan Pemerintah Nomor 43 tahun 2014 tentang desa dalam pasal 93 ayat 1 di jelaskan bahwa pengelolaan keuangan desa meliputi perencanaan, pelaksanaan, penatausahaan, pelaporan, dan pertanggungjawaban. Perdana, (2019) menyatakan bahwa prinsip dasar pengelolaan keuangan daerah yakni prinsip transparan, prinsip akuntabel dan value for money". Sementara Ardini, (2010) menjelaskan bahwa akuntabilitas adalah sebuah dorongan psikologi sosial yang berada dan tertanam dalam diri seseorang dalam menjalankan dan 
menjelaskan tanggung jawab atas apa yang dikerjakan dan dipertanggungjawabkan kepada lingkungannya. Dari penjelasan diatas dapat digambarkan bahwa pengelolaan keuangan desa merupakan kegiatan penataan pengelolaan keuangan ditingkat desa mulai dari perencanaan hingga pertanggungjawaban dengan memenuhi prinsip-prinsip pengelolaan keuangan desa yang sebagaimana telah di aturan dalam PP nomor 43 tahun 2014

\section{Penelitian Sebelumnya}

Penelitian tentang akuntabilitas akan menghasilkan kajian-kajian tentang kemanfaatannya, variabel yang berpengaruh, dan juga teknik-teknik yang biasa digunakan untuk membangun mekanisme akuntabilitas dalam birokrasi, seperti penelitian yang dilakukan Jay P. Desai (2009) di india yang telah berhasil menemukan 5 pilar utama yang perlu di kembangkan agar akuntabilitas publik bisa meningkat. Kelima pilar tersebut adalah (1) informasi publik yang akurat, terbarukan dan disampaikan dengan format sederhana, (2) transparansi dalam proses penyelenggaraan urusan publik, (3) sumber daya, sumber dana, dan sistem pendukung yang cukup untuk menyelenggarakan mekanisme akuntabilitas, (4) hubungan antar aktor independen yang tidak terkooptasi, dan (5) keterlibatan atau partisipasi aktif dari warga. Sejalan dengan hal ini, Paolo Novak (2007) menemukan bahwa penyebab bias kemanfaatan "siapa penerima akuntabilitas" terjadi ketika pemegang kekuasaan lebih cenderung mengutamakan kelompok yang lebih memiliki daya tekan kepada pemerintah sebagai penerima akuntabilitas sehingga kelompok miskin akan tersisihkan.

Ada begitu banyak penelitian terhadulu yang mengkaji tentang akuntabilitas, namun dari hasil penelitian terdahulu yang terindentifikasi belum ada yang secara eksplisit mengangkat tema gangguan fungsi akuntabilitas. Dengan kata lain, penelitian terdahulu belum membidik isu patologi yang menimbulkan disfungsi mekanisme akuntabilitas. Namun secara implisit kajian terdahulu telah memberikan petunjuk gejala patologi yang perlu dieksplorasi dan disusun ekplanasinya lebih lanjut.

Berdasarkan uraian teori dan kajian atas fenomena yang terjadi maka dapat digambarkan kerangka pemikiran sebagai berikut:

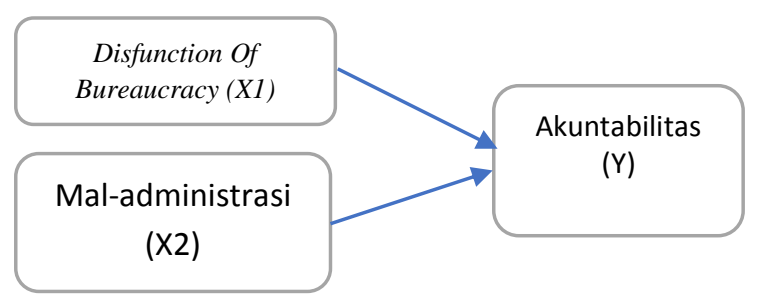

Gambar 1. Kerangka Pemikiran

$\mathbf{H}_{1}$. Disfunction Of Bureaucracy dan Mal-administrasi secara simultan berpengaruh signifikan terhadap akuntabilitas

$\mathbf{H}_{2}$. Disfunction of Bureaucracy secara parsial berpengaruh signifikan terhadap akuntabilitas

$\mathbf{H}_{3}$. Mal-administrasi secara parsial berpengaruh signifikan terhadap akuntabilitas

\section{Metode Penelitian}

Riset ini dilakukan pada Perangkat desa yang ada dilingkungan Kabupaten Boalemo dengan pertimbangan bahwa masih banyak gejala patologi yang ada pada pada birokrasi pemerintahan desa sesuai dengan fenomena yang telah dijelaskan, dengan metode penelitian kuantitatif yang menggambarkan besaran gejala patologi 
birokrasi pemerintah desa terhadap keberhasilan pengelolaan anggaran dana desa di Kecamatan Wonosari Kabupaten Boalemo. Penelitian ini menggunakan dua variabel yakni Patologi Birokrasi sebagai variabel bebas dan keberhasilan pengelolaan dana desa sebagai variabel terikat. Dimensi variabel yang digunakan pada variabel Gejala Patologi adalah Disfunction of Bureaucracy dan Maladministrasi, sementara dimensi yang digunakan dalam keberhasilan pengelolaan dana desa adalah akuntabilitas

Tabel 1 Operasionalisasi Variabel

\begin{tabular}{|c|c|c|c|}
\hline Variabel & Sub Variabel & Indikator & Skala \\
\hline \multirow[b]{2}{*}{$\begin{array}{l}\text { Patologi } \\
\text { Birokrasi } \\
\text { (Ma'ruf M, } \\
\text { 2010) }\end{array}$} & $\begin{array}{l}\text { - Disfunction } \\
\text { of bureaucracy }\end{array}$ & $\begin{array}{ll}\text { 1. } & \text { Struktur } \\
\text { 2. Aturan } \\
\text { 3. } \text { Prosedur }\end{array}$ & Ordinal \\
\hline & - Mal-administration & $\begin{array}{l}\text { 1. Perilaku korup } \\
\text { 2. Tidak sensitive } \\
\text { 3. Arogan, } \\
\text { 4. Mis informasi, } \\
\text { 5. Tidak perduli } \\
\text { dan } \\
\text { 6. Bias } \\
\end{array}$ & Ordinal \\
\hline $\begin{array}{c}\text { Keberhasilan } \\
\text { Pengelolaan } \\
\text { keuangan } \\
\text { desa } \\
\text { (Widyatama. } \\
\text { A, 2017) }\end{array}$ & - Akuntabilitas & $\begin{array}{l}\text { 1. } \begin{array}{l}\text { akuntabilitas } \\
\text { hukum }\end{array} \\
\text { 2. Akuntabilitas } \\
\text { kejujuran, } \\
\text { 3. Akuntabilitas } \\
\text { manajerial } \\
\text { 4. Akuntabilitas } \\
\text { program } \\
\text { 5. Akuntabilitas } \\
\text { kebijakan } \\
\text { 6. Akuntabilitas } \\
\text { finansial }\end{array}$ & Ordinal \\
\hline
\end{tabular}

Metode yang digunakan dalam riset ini adalah metode kuantitatif, selanjutnya dalam proses pengumpulan data peneliti membagikan kuisioner kepada responden dan menjelaskan makna dari setiap pernyataan yang ada pada kuisioner dengan tujuan responden dapat memahami secara jelas sehingga informasi yang diberikan valid dan akurat. Populasi pada riset ini merupakan perangkat desa yang ada dilingkungan kabupaten Boalemo dengan menggunakan sampel cluster, dimana sampel tersebut adalah pemerintah desa yang ada di Kecamatan Wonosari sejumlah 98 responden. Ada beberapa pertimbangan dalam pengambilan Sampel Cluster yang ada diwilayah wonosari, dimana kecamatan wonosari merupakan kecamatan yang jumlah penduduknya banyak dan wilayahnya yang luas, selain itu jumlah desa yang cukup banyak dan juga kucuran dana desa terbesar kedua diwilyah kabupaten Boalemo. Sementara untuk menganalisis data pada penelitian ini menggunakan teknik analisis regresi berganda dan di bantu menggunakan software spss v21. Dalam tahapan pengujian ada tiga langkah yang dilakukan sebelum menguji hipotesisnya: pertama adalah uji instrumen dimana pengujian ini bertujuan untuk menguji ketepatan dan kebenaran data yang telah dikumpul melalui kuisioner dengan dua syarat yakni menguji validitas data (Kesahihan) dan menguji reliabilitas data 
(Keandalan), langkah kedua adalah menguji prasyarat dimana menguji homogenitas dan normalitas data, dan langkah ketiga adalah pengujian hipotesis. Uji regresi linier berganda digunakan untuk menguji hubungan pengaruh antara satu variabel terhadap variabel lain dengan bantuan SPSS versi 21. Model persamaanya dapat digambarkan sebagai berikut: $\mathrm{Y}=\mathrm{b}_{0}+\mathrm{b}_{1} \mathrm{X}_{1}+\mathrm{b}_{2} \mathrm{X}_{2}+\mathrm{e}$

\section{Hasil Dan Pembahasan}

\section{Analisa Hasil}

Deskripsi data pada penelitian ini dikelompokkan menjadi 3 bagian yaitu Disfunction of Bureaucracy (X1), Mal-Administration (X2) dan Akuntabilitas (Y). Gambaran hasil deskriptif setiap variabel dapat dilihat pada tabel 2.

Tabel 2. Tabel Frekuensi

\begin{tabular}{lccccc}
\hline & N & Valid & Miss & Max & Min \\
\hline Disfunction Of Bureaucracy & $\mathbf{9 8}$ & $\mathbf{9 8}$ & $\mathbf{0}$ & 2.76 & 1.08 \\
Administration & $\mathbf{9 8}$ & $\mathbf{9 8}$ & $\mathbf{0}$ & 3.17 & 1.35 \\
Akuntabilitas & $\mathbf{9 8}$ & $\mathbf{9 8}$ & $\mathbf{0}$ & 4.43 & 1.25 \\
\hline
\end{tabular}

Sumber : Olahan Data 2020

Berdasarkan tabel 2 diketahui bahwa variabel dysfunctional of bureaucracy dimana besaran data sebanyak 98 memiliki nila average 1.9890. Nilai rata-rata minimum sebesar 1.08 dan nilai maksimum 2,76 dengan total 194,92 dan standar deviasi 0.42428. Sedangkan untuk variabel mal-administration dengan jumlah data 98 memiliki nilai rata-rata 2.2649. Nilai rata-rata minimum sebesar 1,35 dan nilai maksimum 3,17 dengan total 221,96 dan standar deviasi 0.39133. Sementara itu variabel akuntabilitas dengan jumlah data 98 memiliki nilai rata-rata 3.5128. Nilai rata-rata minimum sebesar 1.25 dan nilai maksimum 4.43 dengan total 344.25 dan standar deviasi 0.58997.

\section{Analisis Regresi Linier Berganda}

\begin{tabular}{|c|c|c|c|c|c|}
\hline \multirow{2}{*}{ Model } & \multicolumn{2}{|c|}{$\begin{array}{l}\text { Unstandardized } \\
\text { Coefficients }\end{array}$} & \multirow{2}{*}{$\begin{array}{l}\begin{array}{c}\text { Standardized } \\
\text { Coefficients }\end{array} \\
\text { Beta }\end{array}$} & \multirow{2}{*}{$\mathrm{T}$} & \multirow{2}{*}{ Sig. } \\
\hline & B & $\begin{array}{l}\text { Std. } \\
\text { Error }\end{array}$ & & & \\
\hline (Constant) & 4.462 & .356 & & 12.549 & .000 \\
\hline $\begin{array}{l}\text { dysfunctional of } \\
\text { bureaucracy }\end{array}$ & -.045 & .168 & -.032 & -.267 & .790 \\
\hline mal-administration & -.380 & .182 & -.252 & -2.087 & .040 \\
\hline
\end{tabular}

a. Dependent Variable: AK

Sumber: Olahan data 2020

Berdasarkan tabel 3, maka persamaan regresi yang terbentuk pada uji regresi ini adalah:

$$
\mathbf{Y}=\mathbf{4 . 4 6 2}-0.045 \mathrm{X}_{1}-0.380 \mathrm{X}_{2}+\mathrm{e}
$$

Model di atas dapat diinterpretasikan bahwa Nilai konstanta adalah 4.462 hal ini menginformasikan jika variabel dysfunctional of bureaucracy dan maladministration bernilai 0 , maka nilai variabel akuntabilitas memiliki nilai 4.462 satuan. Koefisien regresi dysfunctional of bureaucracy $\left(b_{1}\right)$ adalah -0.045 dan bertanda negatif. Hal ini memberikan informasi jika variabel variabel $\mathrm{X}_{1}$ mengalami 
kenaikan satu satuan dan variabel independen lainnya bernilai tetap maka variabel Y mengalami penurunan sebesar 0.045. Selain itu nilai koefisien bertanda negatif menginformasikan bahwa variabel dysfunctional of bureaucracy dengan variabel akuntabilitas memiliki hubungan berlawanan dan dapat diinterpretasikan bahwa akuntabilitas akan rendah jika dysfunctional of bureaucracy meningkat. Sedangkan koefisien regresi mal-administration $\left(\mathrm{b}_{2}\right)$ adalah -0.380. Data ini dapat diinterpretasikan bahwa variabel X2 akan mengalami kenaikan satu satuan jika variabel Y mengalami penurunan sebesar 0.380. Data koefisien bertanda negatif memberikan informasi bahwa hubungan yang berlawanan arah antara maladministration $\left(\mathrm{X}_{2}\right)$ dengan variabel akuntabilitas $(\mathrm{Y})$. semakin tinggi maladministration maka akuntabilitasnya pun akan semakin menurun.

\section{Hasil Uji F}

Uji $\mathrm{F}$ merupakan pengujian yang tujuan adalah menguji variabel-variabel independen secara bersama-sama atau simultan terhadap variabel dependen. Pengujian ini membandingkan nilai signifikan $\mathrm{F}$ dengan nilai yang digunakan yaitu pada level $a=0,05(5 \%)$.

Tabel 4. Uji F

\begin{tabular}{ccccccc}
\hline & Model & Sum of Squares & Df & $\begin{array}{c}\text { Mean } \\
\text { Square }\end{array}$ & F & \multicolumn{1}{c}{ Sig. } \\
\hline 1 & Regression & 2.492 & 2 & 1.246 & 3.7 & .026 \\
& & & & 5 & b \\
& Residual & 31.271 & 95 & .329 & & \\
Total & 33.763 & 97 & & & \\
& & & & &
\end{tabular}

a. Dependent Variable: Auntabilitas

b. Predictors: (Constant), Disfunctional of Bureaucracy, Mal-administration

Sumber: Olahan Data 2020

Berdasarkan tabel 4 anova sig sebesar 0.026 yang berarti secara simultan seluruh variabel independen yakni Disfunctional of Bureaucracy $\left(\mathrm{X}_{1}\right)$ dan MalAdministration $\left(\mathrm{X}_{2}\right)$ berpengaruh signifikan terhadap variabel dependen Akuntabilitas. Dengan demikian, model yang digunakan dalam penelitian ini dapat digunakan untuk menjelaskan pengaruh Disfunctional of Bureaucracy dan Maladministration terhadap keberhasilan pengelolaan alokasi dana desa di Kecamatan Wonosari Kabupaten Boalemo. Dengan demikian $\mathbf{H}_{\mathbf{1}}$ diterima sehingga dapat dinyatakan variabel dysfunctional of bureaucracy dan mal-administration secara simultan berpengaruh signifikan terhadap keberhasilan pengelolaan alokasi dana desa.

\section{Hasil Uji Parsial (Uji t)}

Tabel 5. Uji Parsial

\begin{tabular}{llll}
\hline Variabel & $\mathrm{T}$ & $\mathrm{Sig}$ & Keterangan \\
\hline Konstanta & 4.462 & .000 & \\
$\begin{array}{c}\text { Disfunctional of } \\
\begin{array}{c}\text { Bureaucracy } \\
\text { mal-administration }\end{array}\end{array}$ & -.045 & .790 & $\mathbf{H}_{\mathbf{2}}$ ditolak \\
\hline
\end{tabular}

Sumber: Olahan Data 2020

Pengujian ini berfungsi untuk melihat pengaruh langsung variabel independen terhadap variabel dependen dengan cara melihat signifikansi t hitung dengan syarat nilai signifikan < 0.05. Melalui statistik uji-t yang terdiri dari Disfunctional of Bureaucracy $\left(\mathrm{X}_{1}\right)$ dan Mal-Administration $\left(\mathrm{X}_{2}\right)$ dapat diketahui secara parsial pengaruhnya terhadap akuntabilitas (Y). Berdasarkan tabel uji 
parsial maka persamaan regresi yang terbentuk pada uji regresi ini adalah:

$$
\mathbf{Y}=\mathbf{4 . 4 6 2}-0.045 \mathrm{X}_{1}-0.380 \mathrm{X}_{2}+\mathrm{e}
$$

Pengujian tersebut dapat dinterpretasikan bahwa nilai koofisien ct menunjukan hasil negatif yang memberikan informasi bahwa ada hubungan yang berlawanan arah antara variabel Disfunctional of Bureaucracy dengan variabel akuntabilitas yang menginsyaratkan bahwa semakin tinggi tindakan Disfunctional Of Bureaucracy maka akuntabilitasnya akan semakin buruk. Selain itu variabel mal-administration menunjukan hal yang sama yakni memiliki nilai koofisien yang bertanda negatif, dan bisa diinterpretasikan bahwa semakin tinggi praktek maladministration maka semakin buruk pula akuntabilitas pemerintah.

\section{Pembahasan}

Hasil penelitian menunjukkan bahwa ada pengaruh yang signifikan antara patologi birokrasi terhadap pengelolaan dana desa, dimana hal tersebut dapat dilihat bahwa dysfunctional of bureaucracy dan mal-administration berpengaruh signifikan terhadap akuntabilitas pengelolaan keuangan dana desa di Kecamatan Wonosari Kabupaten Boalemo. Hal ini dapat diartikan bahwa dysfunctional of bureaucracy dan mal administration secara signifikan akan mempengaruhi tingkat keberhasilan dalam pengelolaan keuangan dana desa di Kecamatan Wonosari. Salah satu indikator keberhasilan pengelolaan keuangan dana desa adalah akuntabilitas. Akuntabilitas ini merupakan suatu kewajiban yang tidak dapat ditawar-tawar mengingat masyarakat merupakan target sasaran yang akan menuntut transparansi dan akuntabilitas dalam pengelolaan anggaran dana desa. Akuntabilitas pengelolaan anggaran dana desa ini dimaknai sebagai perwujudan dari kewajiban kepala desa dalam mempertangungjawabkan pengelolaan anggaran dana desa yang telah dipercayakan kepadanya dalam rangka mencapai tujuan yang telah ditetapkan melalui media pertanggungjawaban yang dilakukan secara periodik. Berdasarkan hasil penelitian yang diperoleh peneliti diketahui bahwa gejala patologi birokrasi dalam konsep dysfunctional of bureaucracy yang paling sering terjadi dalam pemerintahan desa berupa penyalah-gunaan wewenang dan jabatan, arogansi, nepotisme, korupsi, ketidakjujuran dan juga mark-up anggaran. Penyalahgunaan wewenang dan juga jabatan yang paling sering terjadi berupa tindakan seenaknya yang dilakukan oleh oknum kepala desa kepada perangkat desa untuk melakukan tindakan yang menyimpang demi kepentingan pribadi. Selain itu penyalahgunaan jabatan juga sering digunakan sebagai senjata untuk melakukan rotasi aparat yang tidak sesuai dengan aturan hanya karena bendahara bekerja tidak sesuai dengan kehendak kepala desa. Penyalahgunaan wewenang, arogansi, ketidakjujuran sampai pada mark-up anggaran sering sekali terjadi karna oknum kepala desa memiliki kewenangan sebagai kuasa pengguna anggaran sehingga banyak bendahara bahkan TPK yang hanya sebatas nama namun semua anggaran dikendalikan langsung oleh kepala desanya sehingga potensi terjadi korupsi semakin terbuka. Hasil ini didapat berdasarkan hasil olahan data atas jawaban responden yang kemudian di olah menggunakan bantuan SPSS.

Widaningrum (2009) menjelaskan bahwa pada dasarnya manajemen dan pengelolaan administrasi pada sektor pemerintah dibuat dan didesain bukan untuk di modifikasi, namun diera ini jika hal itu dilakukan maka bisa jadi sistem yang ada akan mengalami banyak masalah bahkan terancam gagal. Sesungguhnya hal yang sangat penting tetapi sulit untuk dilakukan adalah melakukan perubahan pada sisi nilai-nilai yang membentuk manusia-manusia birokrat itu sendiri. Internalisasi nilai-nilai ini merupakan kunci terhadap peningkatan kinerja dari birokrasi. Selain itu, pemahaman dalam pengelolaan anggaran dana desa juga menjadi hal yang sangat penting yang harus dimiliki oleh aparat desa guna mewujudkan transparansi dan akuntabilitas pengelolaan anggaran dana desa, dan 
siklus pengelolaan anggaran dana desa ini tidak akan berjalan tanpa adanya tata pemerintahan desa yang baik, sehingga perlu adanya peningkatan kualitas sumber daya manusia yang mumpuni, selain itu peran aktif pihak luar seperti masyarakat umum, tokoh masayrakat, dan badan permusyawaratan desa, karena pada dasarnya akuntabilitas pemerintah desa bukan hanya antara pemerintah desa itu sendiri dan pemerintah daerah, namun hirarkinya akuntabilitas pemerintah desa bersifat horizontal dengan Badan Permusyawaratan desa dan bersifat vertikal terhadap masyarakat umum

Sementara secara parsial data menunjukan bahwa dysfunctional of bureaucracy berpengaruh tidak signifikan terhadap akuntabilitas pengelolaan anggaran dana desa. Hal ini dapat diartikan bahwa dysfunctional of bureaucracy tidak secara signifikan mempengaruhi tingkat keberhasilan pengelolaan anggaran dana desa di Kecamatan Wonosari Kabupaten Boalemo. Dalam ruang lingkup patologi birokrasi Dysfunctional of bureaucracy merupakan konsep besar utamanya yang berkaitan dengan regulasi dan prosedur, struktur, karakteristik birokrasi, aturan yang ada pada lembaga pemerintahan yang sifatnya tidak baik yang mengakibatkan buruknya kinerja kelembagaan. Pada dasarnya sifat patologis pada perilaku birokrasi merupakan hal yang tidak berdiri sendiri, melainkan interkasi dari berbagai macam aspek, semisal aspek individual dan juga aspek birokrasi pada birokrat itu sendiri. Adapun aspek-aspek individe yang dimaksud seperti pengharapan, kemampuan, kebutuhan, kepercayaan pribadi, pengalaman, dan untuk aspek birokrasi sendiri misalnya, adanya tugas dalam jabatan, adanya pembagian kerja, adanya wewenang dan tanggung jawab, terdapat sistem pengendalian, terdapat sistem penggajian tertentu. Perilaku birokrasi akan timbul jika kedua aspek ini mengalami interkasi yakni karakteristik birokrasi dan individu (Sartika, 2013)

Berdasarkan riset yang dilakukan oleh peneliti, patologi dalam bentuk perilaku yang sifiatnya disfungsional yang paling sering terjadi adalah kemampuan yang rendah, diskriminatif, tidak disiplin, eksploitasi terhadap bawahan dan juga kondisi kerja yang tidak kondusif. namun hal yang sangat menonjol yang terjadi hampir di semua desa adalah kurangnya disiplin diri. Patologi birokrasi tentang perilaku wajib untuk diteropong dari berbagai sudut pandang, khususnya dari sudut pandang kultur organisasi dan sudut pandang kerja yang berlaku di tiap tiap desa. Kultur organisasi sangat penting untuk dipahami karena memiliki peran sebagai pengontrol perilaku para anggota birokrasi. Hal ini seiring dengan penelitian yang dilakukan oleh (Mantiri, 2017) yang menemukan bahwa tindakan indisipliner yang dilakukan pegawai (ASN) merupakan salah satu bentuk patologi birokrasi. Hal ini disebabkan organisasi memiliki peran aktif dalam menentukan perilaku yang baik dan yang buruk, hal yang tidak wajar dan wajar serta apa yang bisa dilakukan atau tidak. Berdasarkan hasil penelitian dilapangan diperoleh data bahwa dari 98 kuesioner yang dibagikan tidak sedikit perangkat desa yang menjawab wajar apabila sisa anggaran dibagikan kepada pegawai sebagai bonus, namun ada juga beberapa yang tidak setuju apabila sisa anggaran tersebut dibagikan. Hal ini dapat diartikan bahwa kultur organisasi turut menentukan bahwa sesuatu yang tidak baik dapat berlaku dalam setiap kantor dan hal itu akan dianggap sebagai sesuatu yang wajar dan juga sebaliknya. Teruna dalam (Mustafa, 2016) menjelaskan ada beberapa macam bentuk patologi paternalistik yang dapat terjadi misalnya pimpinan yang menganggap dirinya sebagai raja sehingga semua patuh dan tunduk hingga penghormatan yang berlebihan, perlakuan khusus, tidak ada alat pengendali yang mengakibatkan hilangnya tekad karyawan atau bawahan untuk melakukan kritikan terhadap apa yang telah dilakukan pimpinannya. Namun hasil penelitian kali ini menjelaskan bahwa patologi birokrasi jenis ini tidak 
memberikan pengaruh yang signifikan pada akuntabilitas pengolaan anggaran yang ada didesa. Akan tetapi begitu besar penerimaan pendapatan terhadap pembelajaan desa yang begitu besar mebuat kehawatiran tersendiri atas pengelolaan dana desa, untuk itu untuk mengelola dana desa dan memastikan kepercayaan masyarakat maka perlu untuk menerapkan progres akuntabilitas dalam pengelolaan dana desa. Selain itu tujuan utama dari akuntabilitas merupakan sebuah langka atau mekanisme dalam mempertanggungjawabkan kinerja pemerintah desa berdasarkan undang undang yang berlaku dan dilandasi dengan perilaku etis (Mulgan, 2003). Selain itu akuntabilitas bukan hanya untuk mempertanggungjawabakan kinerja keuangan saja, namun ada beberapa hal yang harus di pertanggungjawabkan seperti, pelaksanaan yang disesuaikan dengan regulasi (aturan), ruang lingkup organisasi, pemerintahan dan juga pertanggungjawaban kinerja kepada masyarakat (Patton et al., 2016). Disisi lain mal-administration berpengaruh negatif dan signifikan terhadap akuntabilitas pengelolaan keuangan desa yang ada Kecamatan Wonosari. Hal ini dapat diartikan bahwa mal-administrasi secara signifikan mempengaruhi tingkat ketidak berhasilan pengelolaan keuangan desa yang ada di wilayah Wonosari Kabupaten Boalemo. Mal-administration yang dimaksud adalah kegiatan yang dilakukan yang sangat menyimpang yang berkaitan erat dengan penyogokan, seperti korupsi, tidak peka, perilaku arogan, kesalahan informasi, bias dan sebagainya, yang secara keseluruhan berhubungan dengan kualitas SDM yang ada dalam birokrasi. Kemampuan administrasi merupakan core of goverment dan unsur utama dalam menjalankan roda pemerintahan (Farazman, 2009). Masalah yang besar akan di alami oleh pemerintahan jika kemampuan mengelola administrasi keuangan lemah. Dalam proses pembangunan desa ada beberapa faktor penting yang mempengaruhinya,seperti tingginya partisipasi masyarakat dalam mengembangkan desa, sumber daya manusia (SDM) yang memadai, dan pola kepemimpinan pemerintah desa, (Richard Karauwan;, 2013). Berdasarkan hasil olahan data yang dilakukan oleh peneliti diketahui bahwa penyakit birokrasi yang sering sekali terjadi dari segi mal-administration ini berupa kemampuan yang rendah, diskriminatif, tidak disiplin, eksploitasi terhadap bawahan dan juga kondisi kerja yang tidak kondusif. Akan tetapi hal yang paling menonjol yang terjadi hampir di semua desa adalah kurangnya disiplin diri. Dalam pengelolaan pemerintahan yang baik, aparat desa yang memiliki tanggung jawab besar, dan kemampuan yang memadai dalam mengelola dana desa sangat diperlukan, (Fajri et al., 2015) sehingga pengelolaan keuangan desa tidak akan terhambat. (R.E. Diansari, 2015). Besarnya dana desa yang dikucurkan namun tidak menyediakan SDM, Kapasitas dan kapabilitas pemerintah desa menandakan bahwa lembaga pemerintah desa kurang berkembang dan tidak menjadi strategi yang inheren dalam mebuat formulasi dan kebijakan kebijakan pemerintah desa .Besarnya dana desa yang dikucurkan namun tidak ada penguatan good governance dan penguatan SDM di desa sehingga pengeloaan dana desa memburuk, maka hal tersebut menandakan bahwa pengawasan dari masyarakat yang lemah dan sistem demokrasi yang buruk yang terjadi didesa. Selanjutnya adanya kecenderungan kepala desa yang bertindak one man show memberikan dampak tambahan atas lemahnya pengawasan masyarakat terhadap dana desa, yang menyebabkan miss management dalam pengelolaan dana desa, mulai dari planing, hingga pelaksanaanya dan pada akhirnya banyak kasus korupsi yang terjadi di desa, hal ini disebabkan lemahnya pengawasan pada pihak intern desa. Berdasarkan hal diatas dapat digambarkan bahwa pengelolaan keuangan desa yang berhasil tidak lari dari pernanan aktif desa untuk melakukan penguatan kelembagaan desa dan membangun sistem demokrasi desa yang baik. Sehingga masyarakat desa 
sepatutnya tidak lagi mengadandakan peran Badan Permusyawaratan Desa namun partisipasi seluruhy masyarakat desa dalam melakukan pengawasan secara kolektif dengan tujuan memberikan jaminan atas pengelolaan keuangan yang akuntabel dan legitimate (diterima secara luas oleh seluruh warga desa).

\section{Kesimpulan Dan Saran Kesimpulan}

Berdasarkan hasil dan analisis dapat disimpulkan bahwa Patologi Birokrasi memberikan pengaruh yang signifikan terhadap pengelolaan dana desa dimana hal tersebut dapat dilihat bahwa dysfunctional of bureaucracy dan mal-administration berpengaruh signifikan terhadap akuntabilitas pengelolaan keuangan dana desa di Kecamatan Wonosari Kabupaten Boalemo. Hal ini dapat diartikan bahwa dysfunctional of bureaucracy dan mal administration secara signifikan akan mempengaruhi tingkat keberhasilan dalam pengelolaan keuangan dana desa di Kecamatan Wonosari. Salah satu indikator keberhasilan pengelolaan keuangan dana desa adalah akuntabilitas. Secara simultan dysfunctional of bureaucracy dan mall adminitrasi memberikan pengaruh yang signifikan terhadap gejala patologi birokrasi pemerintah desa, namun secara parsial dysfunctional of bureaucracy tidak memberikan nilai yang signifikan sehingga hipotesis pertama ditolak, sementara itu mall administrasi, memberikan pengaruh signifikan terhadap gejala patologi birokrasi pemerintah desa. Semakin tinggi mal administrasi pada pemerintah desa maka semakin bergejala pula patologi birokrasi pada pemerintah desa.

\section{Saran}

Peneliti menyarankan beberapa upaya tegas yang harus dilakukan oleh pemerintah daerah Kabupaten Boalemo dan salah satu upaya yang dapat dilakukan untuk mengatasi penyakit birokrasi yang pertama adalah dengan melakukan reformasi kelembagaan misalnya dengan membuat perubahan struktur kewenangan dan reformasi dalam sistem dan prosedur layanan. Selain itu penerapan konsep pemerintahan yang baik (good corporate governance) merupakan solusi untuk meminimalisir penyakit birokrasi dengan cara menjalankan pemerintah secara terbuka (transparansi), pengendalian yang baik, dan pertanggungjawaban atas kinerja pemerintah. Hal yang harus diterapkan dalam rangka menegakkan prinsip-prinsip good governance ini adalah dengan melakukan reformasi administrasi, selanjutnya dengan menciptakan kekuatan hukum dan aturan yang jelas dan membentuk sistem pertanggung jawaban dan keterbukaan melalui daring atau E-Government sehingga dapat meningkatkan transparansi dan mampu memperkuat akuntabilitas dari para birokrat. Selanjutnya peneliti sadar bahwa masih banyak faktor lain yang menyebabkan gejala patologi, untuk itu peneliti menyarankan kepada peneliti selanjutnya untuk bisa mengembangkan penelitian ini dengan menggunakan variabel lain diantaranya, variabel pengawasan BPD, Metode verifikasi pengelolaan keuangan, transparansi penggunaan anggaran dan lain sebagainya.

\section{Daftar Pustaka}

Ardini;, L. (2010). Pengaruh kompetensi, independensi, akuntabilitas dan motivasi terhadap kualitas audit. Majalah Ekonomi, 3, 329-349.

Diarespati;, A. W. L. N. (2017). Pengaruh Kompetensi dan Sistem Pengendalian Internal Terhadap Akuntabilitas Pemerintah Desa dalam Mengelola Alokasi Dana Desa ( ADD ). Berkala: Akuntansi Dan Keuangan Indonesia, 02(02), 1-20. https://doi.org/http://dx.doi.org/10.20473/baki.v2i2.4762

E. P. Perdana. (2019). Pengaruh Efektivitas Sistem Pengendalian Internal 
Pemerintah Dan Kinerja Value For Money Terhadap Akuntabilitas Pengelolaan Keuangan Daerah. Doctoral Dissertation, Perpustakaan Fakultas Ekonomi Dan Bisnis Unpas. https:/ / doi.org/10.1017/CBO9781107415324.004

Fajri, R., Setyowati, E., \& Siswidiyanto. (2015). Akuntabilitas Pemerintah Desa Pada Pengelolaan Alokasi Dana Desa (Studi Pada Kantor Desa Ketindan, Kecamatan Lawang, Kabupaten Malang). Jurnal Administrasi Publik (JAP), 3(7), 1099-1104.

Farazman. (2009). Bureaucracy and administration. CRC Pres Taylor \& Francis Group.

H. M. Ma'ruf. (2010). Patologi Birokrasi. Jurnal Visioner, 4(3), 1-16.

Ishak, P. (2018). Pengaruh Independensi Auditor, Emotional Intelligence, Spiritual Intelligence Terhadap Perilaku Etis Auditor dan Kinerja Auditor. ATESTASI: Jurnal Ilmiah Akuntansi, $1(1), \quad$ 85-98. https://doi.org/10.33096/atestasi.v1i1.63

Khoiron; S. L. I. Y. cikusin; (2019). PATOLOGI BIROKRASI ( Studi Tentang Problem-Problem Pengelolaan Badan Usaha Milik Desa ( BUMDes ) pada Desa Wonorejo Kecamatan Singosari Kabupaten Malang ). Jurnal Respon Publik, 13(6), 60-69.

Mantiri, M. (2017). Patologi Birokrasi Pemerintah Kabupaten Minahasa Utara. JURNAL EKSEKUTIF, 1(1).

Meutia; B. D. A. taufiq; I. (2020). Pengaruh Akuntansi Zakat Terhadap Akuntabilitas Publik Badan Amil Zakat Nasional (Baznas) Dan Lembaga Amil Zakat (Laz) Kabupaten/Kota Di Provinsi Sumatera Selatan. Amwaluna: Jurnal Ekonomi Dan Keuangan Syariah, 4(1). https://doi.org/10.29313/amwaluna.v4i1.5326

Mulgan, R. (2003). Holding Power to Account: Accountability in Modern Democracies (1st ed.). Palgrave Macmillan. https://doi.org/10.1057/9781403943835

Muliadi;, ahmat badrun; osgar s matompo; (2019). Pengawasan dana Desa oleh Masyarakat Desa Menurut Undang Undang Nomor 6 Tahun 2014 Tentang Desa. Jurnal Kolaboratif Sains, 1(1). https://doi.org/10.31934/jom.v1i1.708

Mustafa, D. (2016). Tanggung Jawab Dan Responsivitas Birokrasi Pemerintahan Dalam Pelayanan Publik Di Kota Makassar (Studi Kasus Pelayanan Ijin Mendirikan Bangunan (Imb) Di Dinas Tata Ruang Dan Bangunan Kota Makassar). Jurnal Ilmiah Ilmu Administrasi Publik, 5(2), 79-92.

Patton, C. V, Sawicki, D. S., Clark, J. J., Taylor, R., Group, F., \& Routledge, Y. (2016). Basic Methods of Policy Analysis and Planning Third Edition. Routledge is an imprint of the Taylor \& Francis Group, an informa business.

R.E. Diansari. (2015). Analisa Implementasi Alokasi Dana Desa (Add) Kasus Seluruh Desa Di Kecamatan Kledung Kabupaten Temanggung Tahun 2013. Seminar Nasional Universitas PGRI Yogyakarta 2015, 8. http://repository.upy.ac.id/335/

Richard Karauwan; (2013). Tinjauan Tentang Perilaku Kepemimpinan Kepala Desa Dalam Pelaksanaan Pembangunan di Desa Tounelet Kecamatan Kakas Kabupaten Minahasa. Governance, 5(1).

Sartika, D. (2013). Analisis Perilaku Birokrasi Dalam Penyelenggaraan Pelayanan Publik Di Kelurahan Lambara Kecamatan Tawaeli. Katalogis, 1(7), 135-146.

Sholehah, N. L. H. (2019). Analisis akuntabilitas kinerja anggaran dengan perspektif amanah dalam mencegah fraud pada dkad provinsi gorontalo. Jurnal Ilmu Ekonomi PARADOKS, 2(1), 216-228.

Trihastuti, R. (2014). Pengaruh Penerapan Prinsip Akuntabilitas Terhadap Kualitas Pelayanan Di Kantor Bersama Sistem Administrasi Manunggal Satu Atap (SAMSTA) Surabaya Timur. Publika, 2(3), 1-10. 
Wakhid, A. A. (2011). Eksistensi Konsep Birokrasi Max Weber Dalam Reformasi Birokrasi Di Indonesia. Jurnal Teropong Aspirasi Politik Islam, 7(2). https://doi.org/https://doi.org/10.24042/tps.v7i2.1540 